\title{
Diversity, Habitat Utilization and Nesting Characteristics of Waterbirds in and around Maduru Oya Reservoir in Maduru Oya National Park, Sri Lanka
}

\author{
Kulathungage Hiranthi Dilrangi $₫$, Wathmini De Silva $₫$, Dharshani Mahaulpatha* ${ }^{*}$ \\ Department of Zoology, Faculty of Applied Sciences, University of Sri Jayewardenepura, Gangodawila, Nugegoda, Sri Lanka \\ Email: *mahaulpatha@sjp.ac.1k
}

How to cite this paper: Dilrangi, K.H., De Silva, W. and Mahaulpatha, D. (2021) Diversity, Habitat Utilization and Nesting Characteristics of Waterbirds in and around Maduru Oya Reservoir in Maduru Oya National Park, Sri Lanka. Open Journal of Ecology, 11, 664-689.

https://doi.org/10.4236/oje.2021.1110042

Received: September 6, 2021

Accepted: October 10, 2021

Published: October 13, 2021

Copyright $\odot 2021$ by author(s) and Scientific Research Publishing Inc. This work is licensed under the Creative Commons Attribution International License (CC BY 4.0).

http://creativecommons.org/licenses/by/4.0/

\begin{abstract}
Maduru Oya National Park (MONP) including its largest reservoir, Maduru Oya Reservoir (MOR), has been identified with a high waterbird density. However, a limited number of researches have been conducted on waterbirds in MONP. In this study, diversity, habitat use of waterbirds at MOR and their nesting characteristics were analyzed. Bird survey was carried out using the point count method and block count method. A common ethogram was constructed to identify the behavior categories. Percentage cover of habitat types was estimated by quadrat method. A total of 30 species belonging to 15 families were recorded, including two globally threatened species and three winter visitors. Year around Shannon-Weiner index for MOR was 1.491. Little Cormorant had the highest relative abundance. Percentage coverage of grass had increased gradually from March to September with the highest in September $(69.27 \%)$ while open water had the highest coverage in the other months. Significantly high number of individuals used areas of grass, open water and mud for feeding and exposed rocks, dead trees/logs for resting (One-way ANOVA, $\mathrm{p} \leq$ 0.05). Four waterbird species were observed building nests. Occupied nesting tree species were Senna spectabilis (Kaha Kona), Dymorphocalyx glabellus (Weliwanna) and Alstonia scholaris (RukAththana). The number of nests observed in three layers of canopy was significantly different $(\mathrm{p} \leq 0.05)$. The highest average number of nests was observed in middle layer $(8.90 \pm 2.67)$. Black-headed Ibises had high preference to nest in Dymorphocalyx glabellus $(\mathrm{p} \leq 0.05,3.30 \pm 1.32)$ while Great Cormorants $(\mathrm{p} \leq$ $0.05,2.38 \pm 0.74)$ and Grey Herons ( $\mathrm{p} \leq 0.05,4.27 \pm 2.12)$ in Alstonia scholaris. Little Cormorants had no significant difference in their preference for nesting trees. As a preliminary study, this can be used for future research on
\end{abstract}


waterbirds and to compose management and conservation plans.

\section{Keywords}

Aquatic Avifauna, Conservation, Wetlands, Nesting Ecology

\section{Introduction}

Wetland habitats constitute permanent or temporary accumulation of water with associated floral and faunal communities [1]. Wetlands support and maintain a diverse community of waterbirds by providing important habitats for their feeding, resting, breeding and other social interactions [2] [3]. The Ramsar Convention defines waterbirds as "species of birds that are ecologically dependent upon wetlands" [4]. Some important factors affecting the relationship between wetlands characteristics and waterbirds include the availability of habitats, quality water, food, shelter and protection from predators. Comprehension of waterbird species diversity and abundance in wetland ecosystems is important in selecting areas for designing regional conservation strategies [5]. Approximately 164 species of waterbirds recorded in Sri Lanka belong to the 23 families [6] [7]. Waterbirds inhabit a wide variety of wetlands throughout Sri Lanka and large concentrations are found in the coastal and inland wetlands of the dry zone [6].

Maduru Oya National Park (MONP) lying within the dry zone of Sri Lanka, was established as an integral part of the Mahaweli Protected Area Complex to provide refuge for many native fauna and flora, particularly elephants and a large number of waterbird species [8] [9]. The park is 58,850 ha in extent of which the wetlands constitute around 10,000 ha. The wetlands within MONP constitute the immediate catchments of five reservoirs including the Maduru Oya (6100 ha), Ulhitiya (2270), Ratkinda (1100 ha), NDK (700 ha) and Henanigala (800 ha) [8]. The mean annual rainfall within the area is $1650 \mathrm{~mm}$ received mostly during the northeast monsoon season and the mean annual temperature of the area is about $27^{\circ} \mathrm{C}$ [10]. Wetlands of MONP have been identified as Important Bird and Biodiversity Area (IBA) with high waterbird density and it supports globally threatened (VU) species including Asian Woollyneck (Ciconia episcopus) and Lesser Adjutant Stork (Leptoptilos javanicus) [6] [11] [12].

A number of studies have been conducted focusing the bird diversity in several national parks in Sri Lanka including Wilpattu National Park, Wasgomuwa National Park, Minneriya National park, Gal-oya National Park and in Yala protected area complex [13] [14] [15] [16] [17]. However, the amount of research work conducted on birds in MONP is incipient. Up to date only the avifaunal diversity in the peripheral areas of the MONP has been studied [18]. Despite being the third largest national park in Sri Lanka, the avifauna inside the MONP has not been systematically documented leading to the gaps in the knowledge on the waterbirds and their habitat use. A sound understanding of 
how waterbird species interact with existing habitats around wetlands is essential to aid with developing effective conservation plans. Therefore, the objectives of this study were to investigate diversity, habitat use of waterbirds and their nesting characteristics at MOR.

\section{Materials and Methods}

\subsection{Study Area}

The study was conducted monthly from January to December 2019 at the Maduru Oya Reservoir (MOR). MOR is the largest reservoir found within the park with a catchment area of $453 \mathrm{~km}^{2}$ and a storage capacity of 596,000,000 $\mathrm{m}^{3}$ [8] [10]. Although MOR is a very large reservoir, one of the main constrains faced is selecting the sites for bird sampling due to inaccessibility to the sites throughout the year. Four representative sampling sites were selected covering all the accessible parts of the reservoir during the preliminary survey, considering the accessibility and the highest visibility of the sites. The four sites were $7^{\circ} 38^{\prime} 44^{\prime \prime} \mathrm{N}$, $81^{\circ} 09^{\prime} 59^{\prime \prime E}$ (Site 1), $7^{\circ} 38^{\prime} 21^{\prime \prime N}, 81^{\circ} 11^{\prime} 56 " \mathrm{E}$ (Site 2), $7^{\circ} 39^{\prime} 55^{\prime \prime N}$, 81 ${ }^{\circ} 12^{\prime} 41^{\prime \prime E}$ (Site 3) and $7^{\circ} 34^{\prime} 47^{\prime \prime N}, 81^{\circ} 06^{\prime} 35^{\prime \prime} \mathrm{E}$ (Site 4) (Figure 1). Bird sampling and collection of data to determine habitat variation and habitat use were carried out at the four sites. Survey on nesting habitat characteristics was conducted in a nesting site $\left(7^{\circ} 38^{\prime} 25.00^{\prime \prime} \mathrm{N}, 81^{\circ} 11^{\prime} 44.22^{\prime \prime} \mathrm{E}\right)$ situated within the sampling site 1 which appears as an island during the dry season of the year.

\subsection{Bird Sampling}

The study time period covered one dry season (March-September) and one wet season (October-February) [19]. Bird census was carried out at four sampling sites monthly, for four consecutive days per month using the point count method [20] [21]. All bird species and individuals seen from a fixed point were recorded to a radius of approximately $300 \mathrm{~m}$, depending on visibility [22]. Each count was recorded for a duration of fifteen minutes during the early morning $(0060 \mathrm{~h}-1000 \mathrm{~h})$ when bird activity was high. Fifteen minutes count enabled recording all the individuals with minimal efforts and disturbances [23] [24]. Tally counters were used for the counting of birds. Bird observations were done using Nikon Monarch $(15-60) \times 25$ spotting scopes and Nikon Monarch $12 \times 42$ binoculars. Species those were difficult to identify on-site were photographed or identifying characteristics were noted on field note book and later clarified using field guide [25]. Flocks larger than hundred individuals were estimated by counting blocks of $10,20,50$ or 100 birds and estimating similar-sized groups in the flock [26]. Possible predators of the waterbird species were identified through direct observations and via photographs captured in camera traps of an ongoing research inside the MONP. Species identification was done using the standard field guide of Harrison and Worfolk and classification, nomenclature of the bird's checklist were done according to Birdlife International 2020a [27] [28]. 


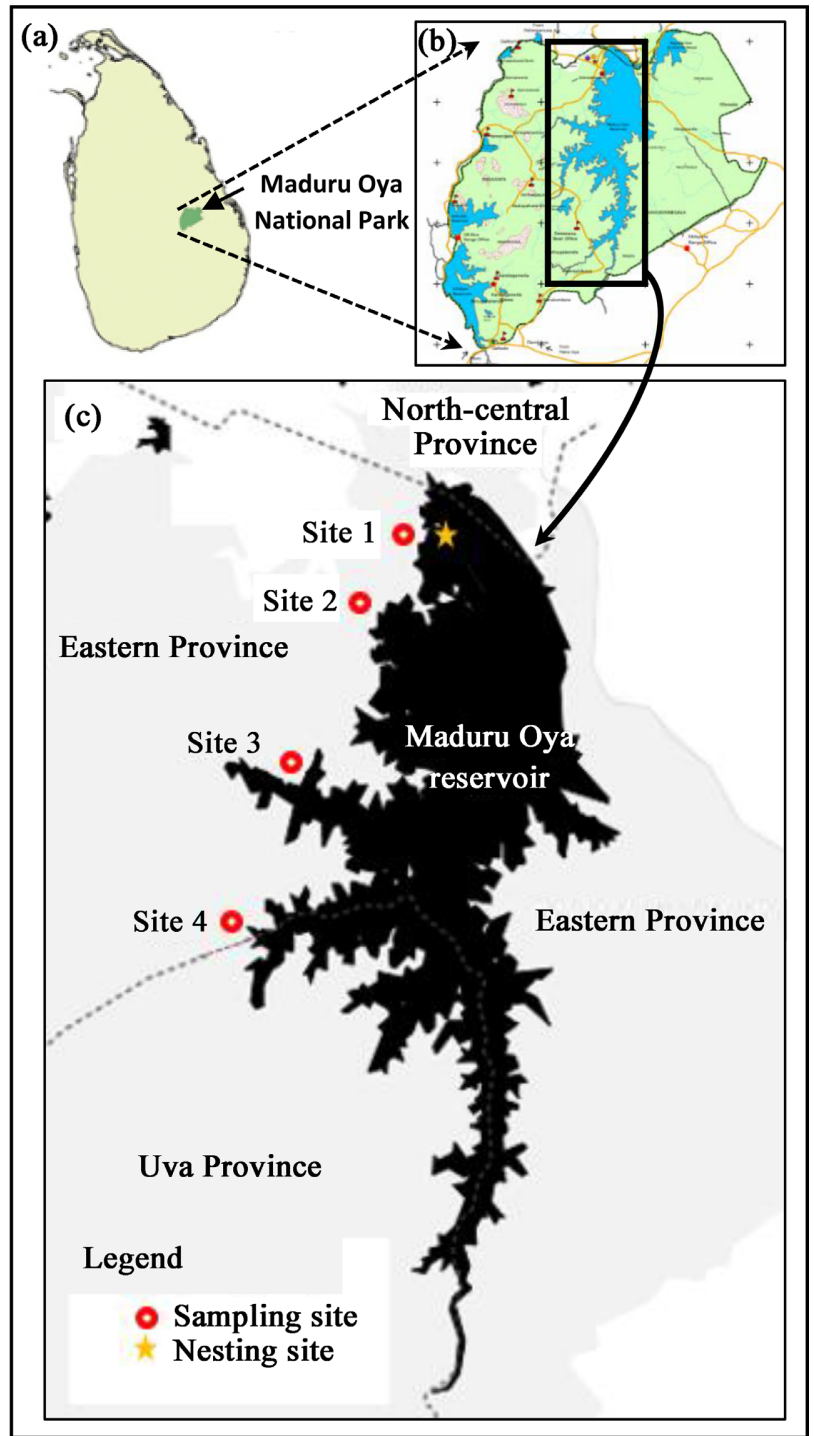

Figure 1. (a) Study area map that shows the location of MONP in Sri Lanka; (b) MOR inside the MNOP; and (c) four sampling sites and the nesting site of the survey, Image source; Google Earth Pro Software.

\subsection{Habitat Variation and Habitat Use}

A common ethogram was constructed using behavioral sampling methods to identify the behavior categories of waterbirds [29]. Behavioral data were collected under the categories of feeding, resting, breeding and comfort activities (Appendix A). Behavior at the first sight and the habitat type they used to exhibit the particular behavior were recorded for each bird in each point count to assess habitat utilization [30]. Habitat types used by waterbirds were identified based on field observations done in the preliminary survey and categorized as open water, grass, mud, rock, invasive plants, non-vegetative cover, dead trees/logs and trees. Monthly habitat variation was assessed by estimating the percentage cover of each habitat type at each sampling site along three $300 \mathrm{~m}$ long fixed line transects. Along each line transect, eight large quadrates $(20 \times 20 \mathrm{~m})$ were laid 
keeping a $20 \mathrm{~m}$ distance between each two quadrates. Within each $20 \times 20 \mathrm{~m}$ quadrate four random quadrates $(5 \times 5 \mathrm{~m})$ were laid to estimate the percentage cover of habitats ([31] with modifications) (Figure 2). The large quadrates $(20 \times$ $20 \mathrm{~m}$ ) were used to locate the small quadrates easily. The number of dead trees/logs and trees in each quadrate were also counted and recorded.

\subsection{Nesting Habitat Characteristics}

Data collection was carried out monthly for three consecutive days per month from March to June 2019 during the breeding season. Visual surveys of nesting birds were conducted in the early morning (half an hour before sunrise until one hour later) and evening (one hour before sunset until dark) using Nikon Monarch (15 - 60) $\times 25$ spotting scopes and Nikon Monarch $12 \times 42$ binoculars [32].

Identification of nesting trees was done with the aid of standard tree identification guides. Locations of nesting trees were determined using Global Positioning System (GPS-Garmin e Trex Euro). GPS points were entered into an online Google Earth map of MOR to calculate the area of the nesting site. Random quadrats $(10 \times 10 \mathrm{~m})$ were laid for the sampling of nesting trees. The canopy of each nesting tree was visually divided into three approximately equal parts as upper canopy layer, middle canopy layer and lower canopy layer [33] (Figure $3(\mathrm{a})$ ). Number of nests belonging to each waterbird species in each layer of the canopy was counted. Bole height and canopy height of those identified nesting trees were measured using SUNTO, PM-5/360PC Clinometer [34] (Figure 3(b)). Diameter at breast height (DBH) of nesting trees was measured at approximately $1.3 \mathrm{~m}$ above ground using a measuring tape [35].

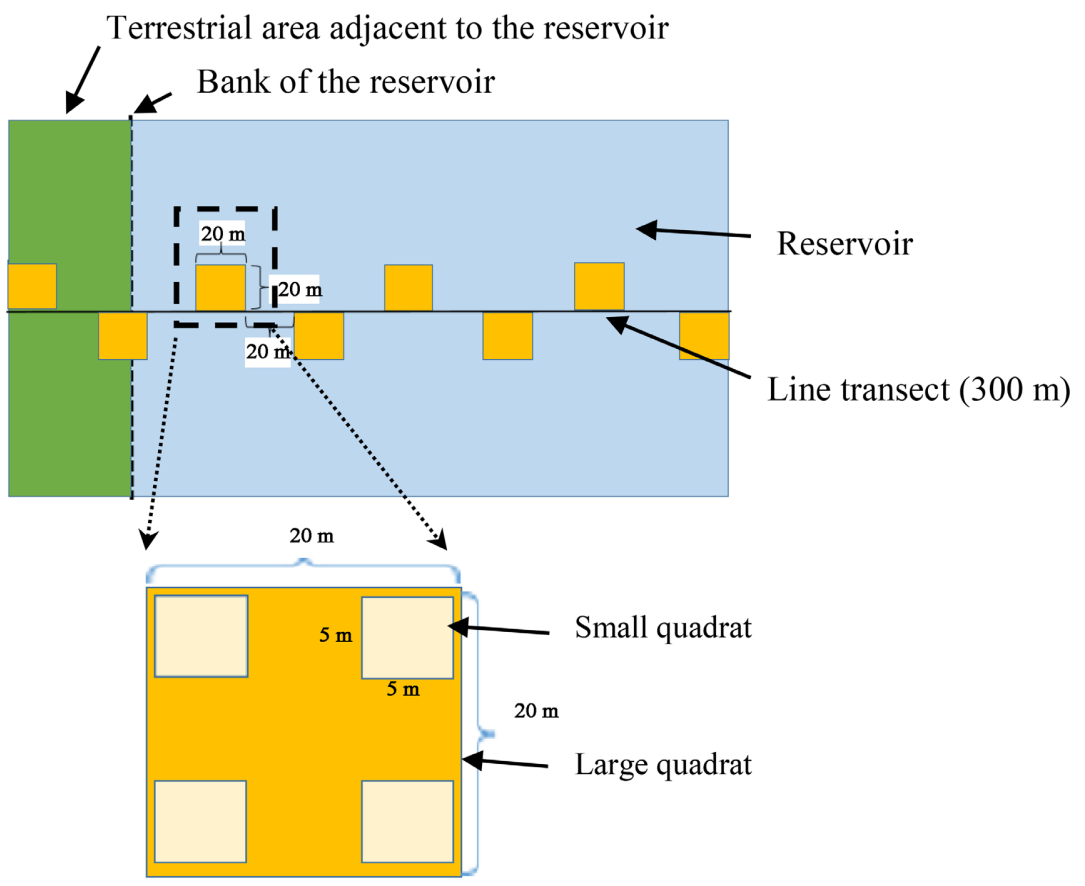

Figure 2. Illustration of quadrate method used to determine percentage habitat cover along line transects. 

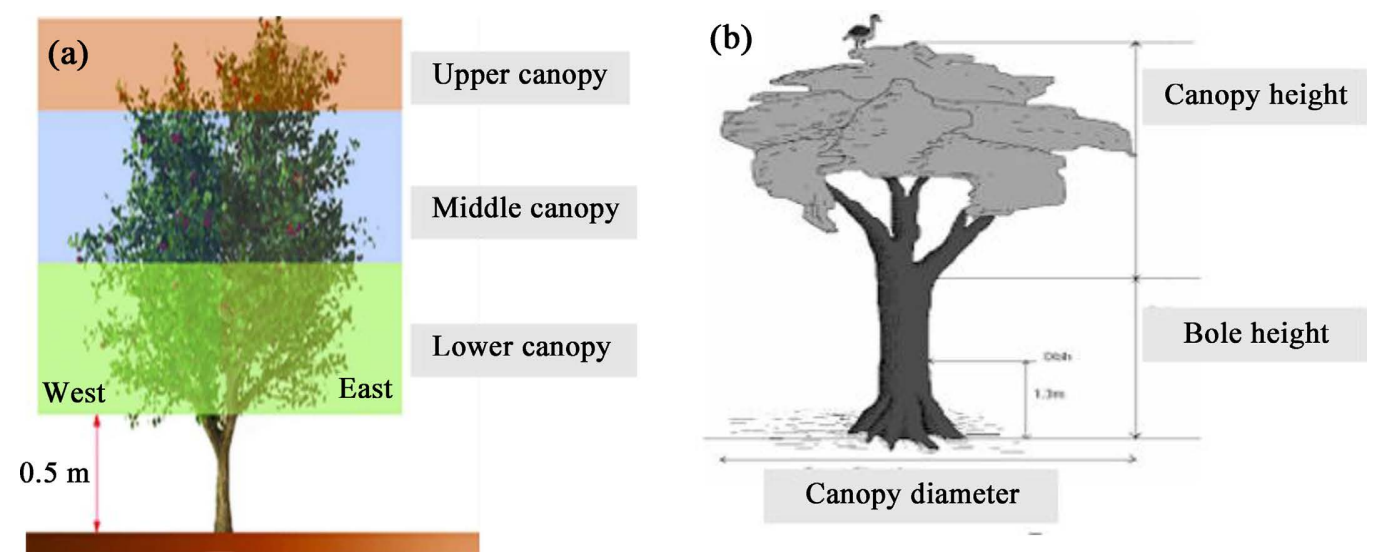

Figure 3. (a) Illustration of the layers of the canopy of a nesting tree; (b) Illustration of the Bole height and canopy height and canopy diameter of a nesting tree.

\subsection{Statistical Analysis}

Counts of birds were pooled to produce a single dataset per month. The number of water birds of each species recorded was used to calculate Shannon-Weiner index $\left(H^{\prime}\right)$ [36]. Relative abundance of each species was calculated as a percentage of the proportion between average number of individuals per species and average number of all individuals [37]. Commonness was assessed as, very common (VC) (seen on 75\% - 100\% of visits), common (C) (50\% - 74\%), uncommon (UC) (25\% - 49\%) and rare (RA) (<25\%) [38]. Minitab Version 17' statistical software package and Microsoft excel 2013 were used for statistical analysis and graphical representation of results. One-way analysis of variance (ANOVA) was used to compare the number of waterbirds performing different behavior categories in each habitat type. An Arc-sin transformation was performed prior to analysis of the diurnal activity data as the percentage activity values were not normally distributed. Tukey's test was used to determine which means are significantly different from each other. Finally the most utilized habitat types by water birds to perform each behavior were assessed. One-way ANOVA was used to compare the canopy height, bole height, tree height, canopy diameter, DBH between three different nesting tree species. Same test was employed to compare the mean number of nests in three different canopy layers (Upper, Middle, Lower) and to compare the mean number of nests of each water bird species observed in three different tree species. Tukey's test was used to determine which means are significantly different from each other.

\section{Results}

\subsection{Bird Sampling}

A total of 41,151 individuals were recorded in and around MOR during the study period, covering six orders, fifteen families and 30 species (Appendix B). This included two globally threatened species; Lesser Adjutant Stork (Leptoptilos javanicus) (Figure 4(a)) and Asian Woollyneck (Ciconia episcopus) (Figure 
4(b)), two locally threatened species including Little Ringed Plover (Charadrius dubius) (Figure 4(e)), three locally nearly threatened species including Great Cormorant (Phalacrocorax carbo), Black-crowned Night-heron (Nycticorax nycticorax) (Figure 4(d)). It also included three winter visitors; Common Sandpiper (Tringa hypoleucos) (Figure 4(c)), Common Greenshank (Tringa nebularia) and Whiskered Tern (Chlidonias hybridus).

A great variation in monthly waterbird abundance was observed in and around the MOR. The highest waterbird abundance was recorded in June which was 7292 and the lowest was recorded in December which was 338 (Figure 5(a)). The highest species richness of 27 was recorded in August while the lowest of 19 was recorded in January (Figure 5(b)). A very high abundance of waterbirds was recorded in the dry season compared to wet season (Figure $5(\mathrm{c})$ ). The

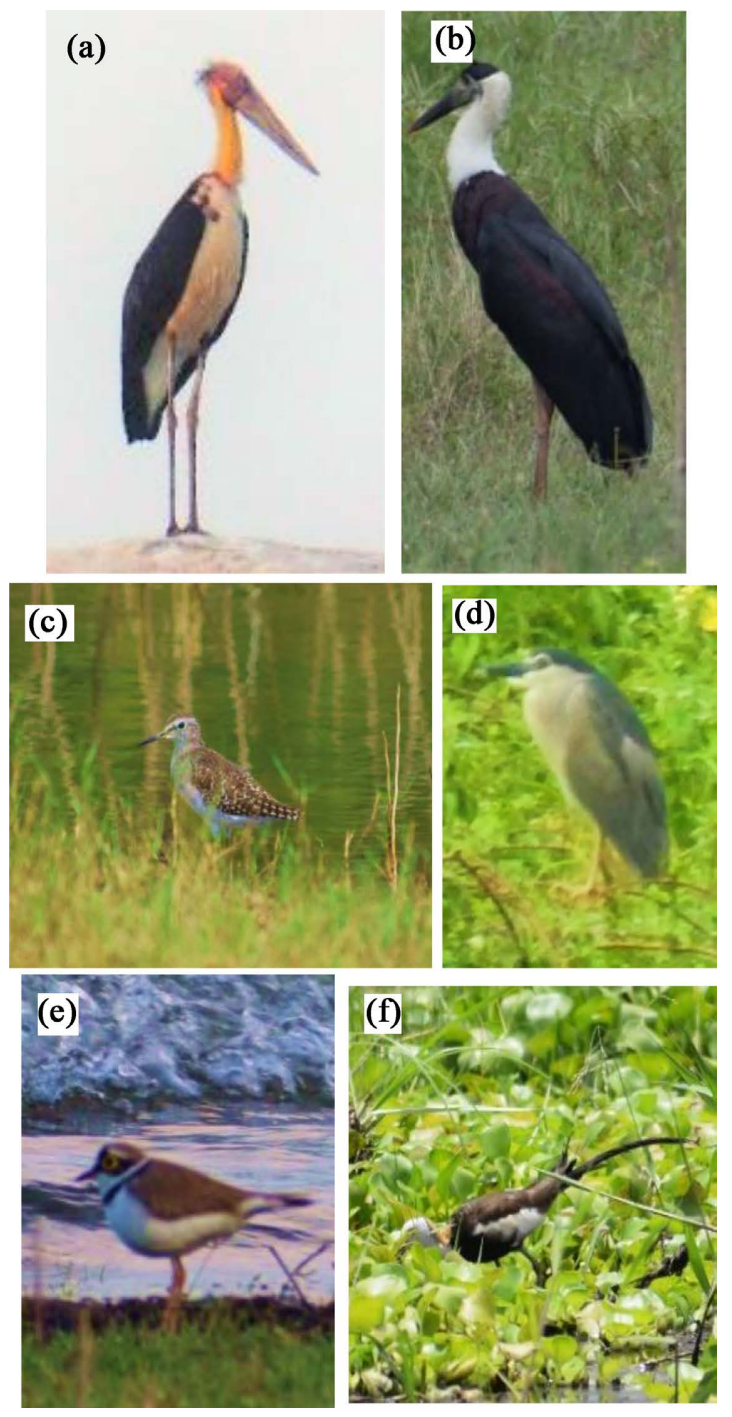

Figure 4. (a) Lesser Adjutant Stork (Leptoptilos javanicus); (b) Asian Woolyneck (Ciconia episcopus); (c) Common Sandpiper (Tringa hypoleucos); (d) Black-crowned Night-heron (Nycticorax nycticorax); (e) Little Ringed Plover (Charadrius dubius); (f) Pheasant-tailed Jacana (Hydrophasianus chirurgus). 


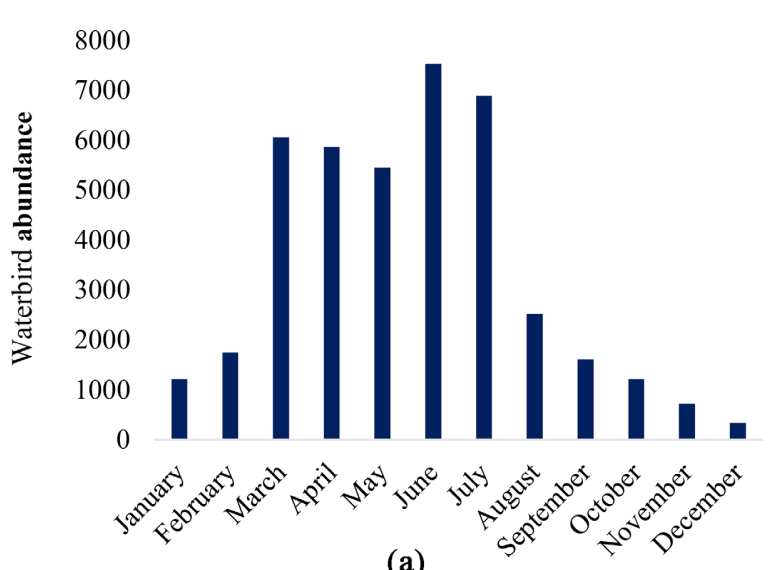

(a)

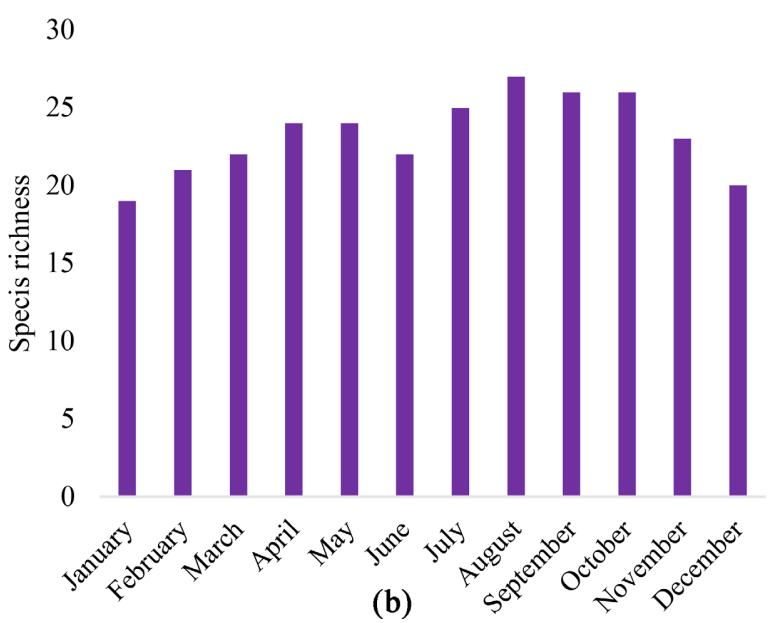

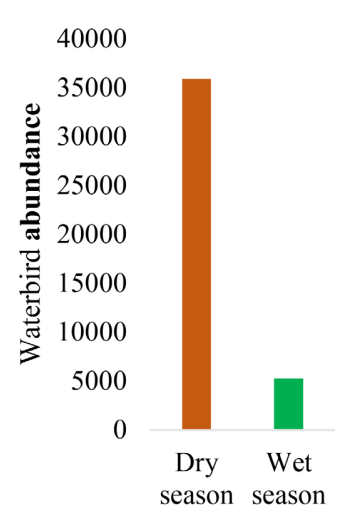

(c)

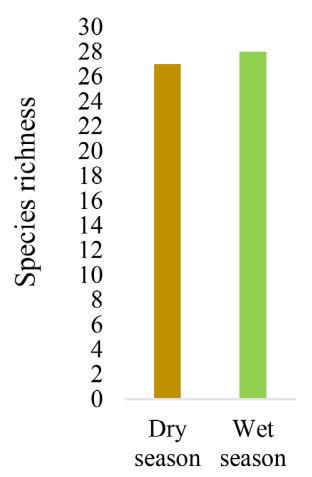

(d)

Figure 5. (a) Monthly variation of waterbird abundance, (b) Monthly variation of species richness, (c) Seasonal variation of waterbird abundance, (d) Seasonal variation of species richness.

species richness of the dry season was 27 and for the wet season 28 . Therefore, there was no considerable difference between species richness between the dry season and the wet season (Figure 5(d)).

The calculated Shannon-Weiner index varied throughout the year. The highest waterbird species diversity was obtained in September (2.41) followed by December (2.35). The lowest species diversity 0.94 was obtained in March (Figure 6(a)). The Shannon-Weiner index of waterbirds was 1.073 and 2.033 for the dry season and wet season respectively (Figure 6(b)). The year around Shannon-Weiner index obtained for the MOR reservoir was 1.491. The relative abundance of waterbirds varied within a range of $64.81 \%-0.01 \%$. Among all other recorded species, Little Cormorant had the highest relative abundance (64.81\%) while Asian Woollyneck (0.01\%) had the lowest relative abundance (Appendix C). Twenty one species of waterbirds were recorded as very common bird species, whereas; three species were recorded as common bird species; Oriental Darter, Eurasian Spoon Bill and Asian Woollyneck. Pheasant-tailed Jacana (Figure 6(f)) and Lesser Whistling-duck were recorded as uncommon bird species. The only rare bird species recorded was Black-crowned Night-heron 
(Appendix D). Fishing cat (Prionailurus viverrinus), fresh water crocodile (Crocodylus palustris), Sri Lankan Leopard (Panthera pardus kotiya) and Land monitor (Varanus bengalensis) (Figure 7) were recorded as possible predators of waterbirds in and around the reservoir.

\subsection{Habitat Variation and Habitat Use}

Availability of habitat types varied greatly throughout the year. The reservoir was eventually dried out from April to September with the lowest obtained percentage cover of open water in September (12.49\%). Percentage cover of grass was gradually increased from March to September with the highest obtained cover in September (69.27\%). During the rest of the months, open water was the most prominent habitat type in the MOR with the highest in December (91.1\%). No invasive plant cover was recorded from June to September (Figure 8). Eichhornia crassipes (Water Hyacinth), Salvinia molesta (Salvinia) and Ludwigia sp. were the invasive plant species found within the reservoir (Figure 9).

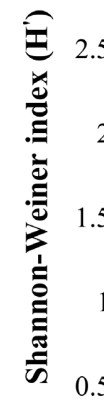

0

0

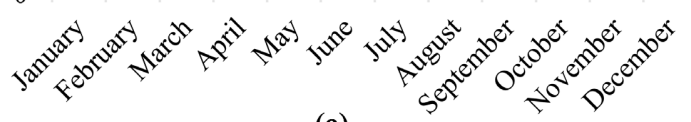

(a)
2.5

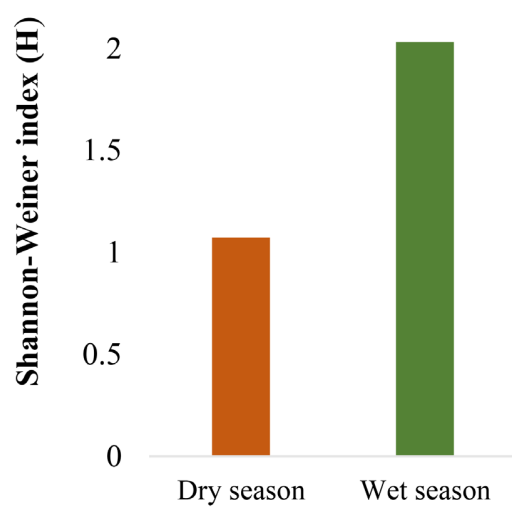

(b)

Figure 6. (a) Monthly variation of the Shannon-Weiner index (H') of waterbirds; (b) Seasonal variation of the Shannon-Weiner index (H') of waterbirds.

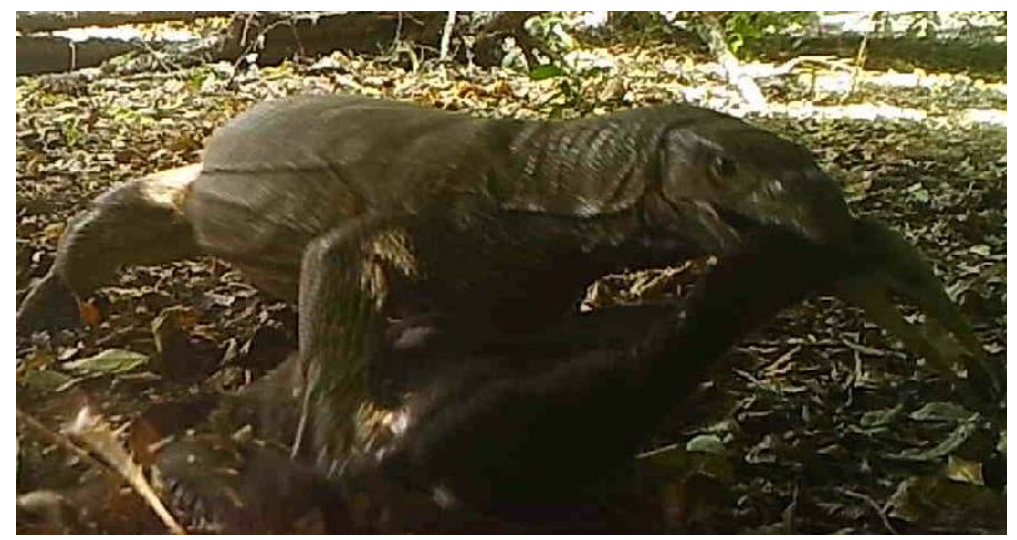

Figure 7. Predation of Little Cormorant by Varanus bengalensis captured in a camera trap (Photo: Dulan Jayasekara). 


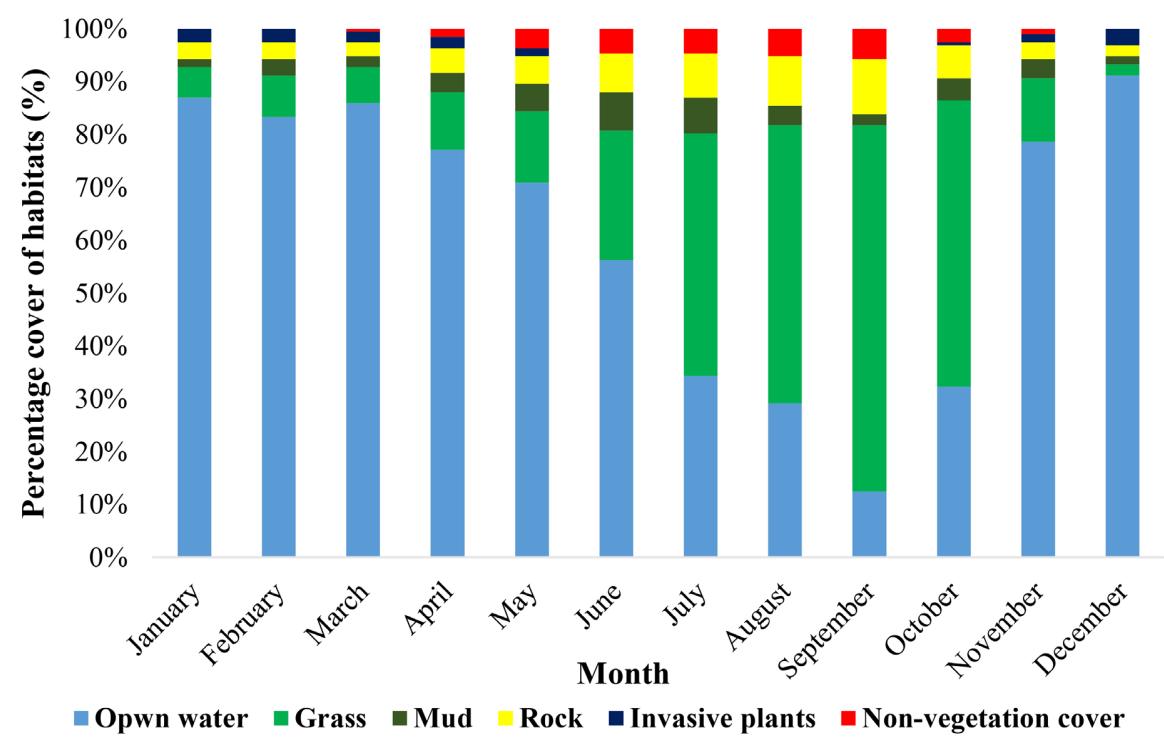

Figure 8. Monthly variation of the percentage of habitat types in and around the MOR.
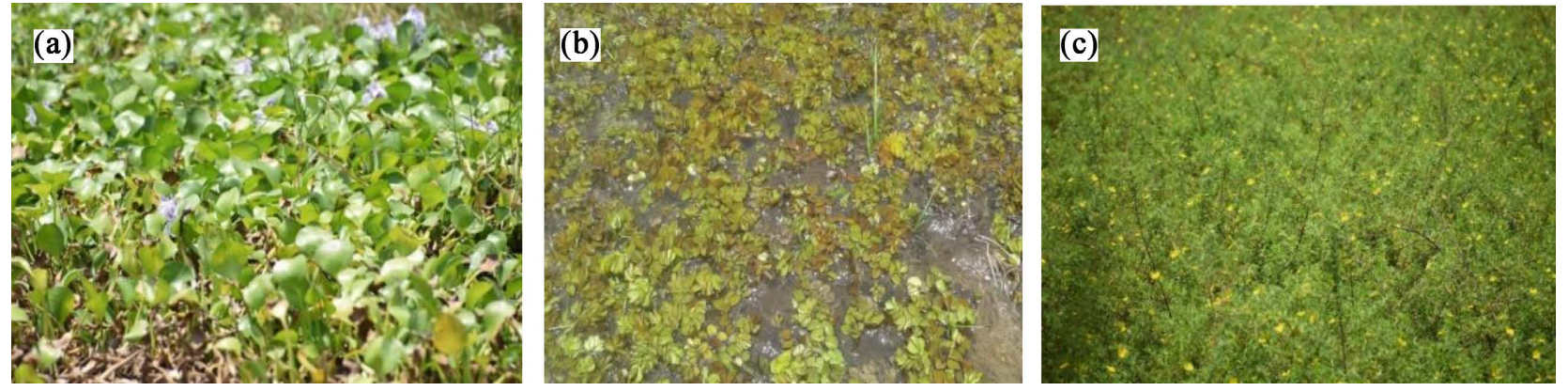

Figure 9. (a) Eichhornia crassipes (Water Hyacinth), (b) Salvinia molesta (Salvinia) and (c) Ludwigia sp.

The dead trees/logs and rocks were fully inundated when the reservoir was filled with water and they gradually emerged from April to September with the eventual drying up of the reservoir. The number of trees which were utilized by waterbirds around the reservoir was almost constant throughout the year.

The most utilized habitat type of waterbirds was trees, followed by rocks and open water. The most underutilized habitat was invasive plants (Figure 10). Feeding was the highest observed behavior in open water, grassy areas and in areas with mud ( $\mathrm{p} \leq 0.05$; Tukey's pairwise test after one-way ANOVA) when compared to the other behaviors. Resting the highest observed behavior in areas with rock, dead trees/logs and invasive plants ( $\mathrm{p} \leq 0.05$; Tukey's pairwise test after one-way ANOVA). Tree habitat was the only habitat type which was accommodated for the breeding behavior of the waterbirds (Table 1).

\subsection{Nesting Habitat Characteristics}

The calculated area of the nesting site was $6542 \mathrm{~m}^{2}$. Little Cormorant (Microcarbo niger) and Great Cormorant (Phalacorocorax carbo) belonging to family Phalacrocoracoracidae, Grey Heron (Ardea cinerea) belonging to family Ardeidae and Black-headed Ibis (Threskiornis melanocephalus) belonging to family 
Threskiornithidae were observed building nests (Figure 11). Little Cormorant was the most abundant nesting species throughout the nesting season. Kaha Kona (Senna spectabilis), Weliwanna (Dymorphocalyx glabellus) and Ruk Aththana (Alstonia scholaris) were the most recorded nesting tree species (Figure 12).

The mean canopy height and mean canopy diameter were significantly different between three tree species ( $\mathrm{p} \leq 0.05)$, with the maximum values were recorded in Rukaththana followed by Kahakona and Waliwanna. The highest values of mean bole height, mean tree height and mean DBH were recorded in Rukkaththana and these values were significantly different than the corresponding values of other two tree species (Table 2).

There was no significant difference between the mean numbers of nests built in three nesting tree species by the Little Cormorants $(p>0.05)$. However the

1200
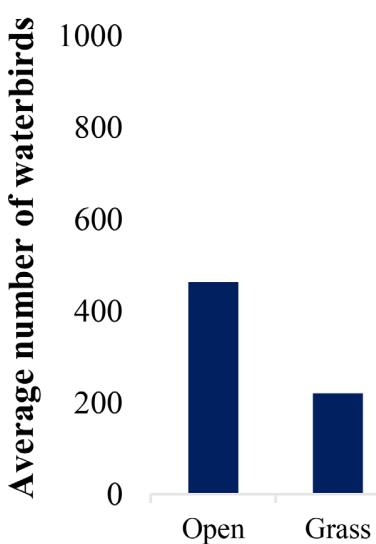

Water

Grass

Mud

\section{Habitat type}

plants vegetation trees/Logs cover

Figure 10. Average number of individuals observed in different habitat types.

Table 1. Variation between the different behaviors shown by waterbirds in different types of habitats.

\begin{tabular}{cccccc}
\hline \multirow{2}{*}{ Habitat } & \multicolumn{5}{c}{ Behavior category } \\
\cline { 2 - 5 } & Feeding & Resting & Comfort activities & Breeding & \\
\hline Open water & $407.00^{\mathrm{A}}$ & $0.58^{\mathrm{B}}$ & $29.50^{\mathrm{B}}$ & - & $0.000^{*}$ \\
Grass & $106.20^{\mathrm{A}}$ & $57.20^{\mathrm{B}}$ & $33.17^{\mathrm{BC}}$ & - & $0.042^{*}$ \\
Mud & $142.10^{\mathrm{A}}$ & $38.17^{\mathrm{B}}$ & $24.00^{\mathrm{B}}$ & - & $0.028^{*}$ \\
Rock & - & $288.1^{\mathrm{A}}$ & $45.25^{\mathrm{B}}$ & - & $0.011^{*}$ \\
Invasive plants & $4.750^{\mathrm{B}}$ & $14.25^{\mathrm{A}}$ & $3.33^{\mathrm{B}}$ & - & $0.003^{*}$ \\
Non vegetation cover & $142.8^{\mathrm{B}}$ & $212.10^{\mathrm{A}}$ & $12.42^{\mathrm{B}}$ & - & 0.175 \\
Dead trees / logs & - & $895.00^{\mathrm{A}}$ & $12.75^{\mathrm{B}}$ & - & $0.000^{*}$ \\
Trees & - & $45.40^{\mathrm{B}}$ & 0 & $1009.10^{\mathrm{A}}$ & $0.000^{*}$ \\
\hline
\end{tabular}

${ }^{*}$ Differ significantly (One-way ANOVA test, $\mathrm{p} \leq 0.05$ ) between behavior categories. Means followed by the same superscript letter do not differ significantly (Tukey's test, $\mathrm{p} \leq 0.05$ ). 

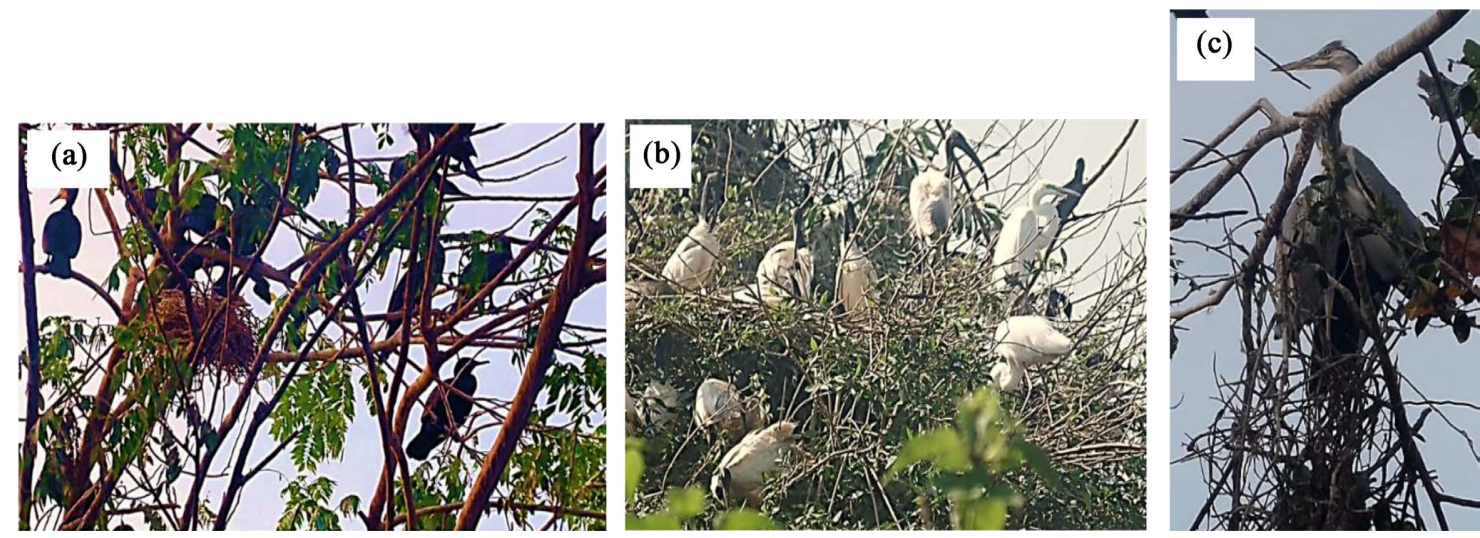

Figure 11. (a) Cormorants; (b) Black headed Ibis (Threskiornis melanocephalus); (c) Grey Heron (Ardea cinerea).
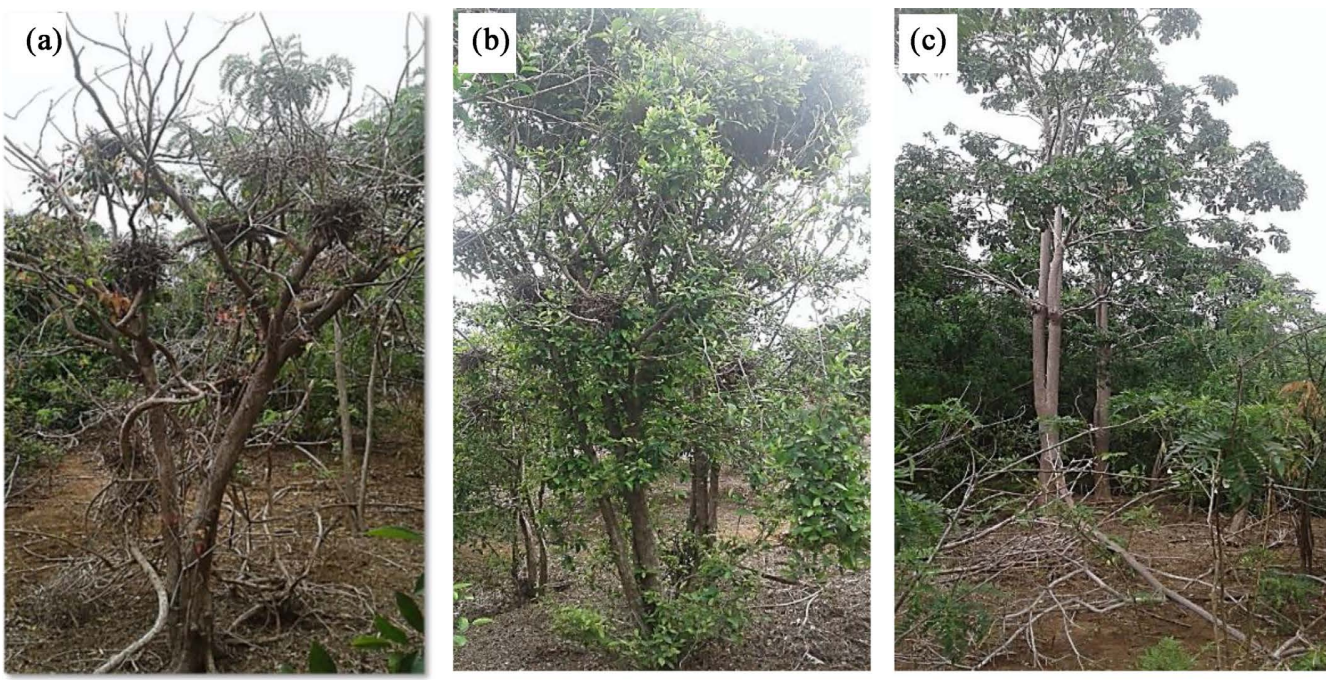

Figure 12. 12 Kaha Kona (Senna spectabilis), Weliwanna (Dymorphocalyx glabellus). Ruk Aththana (Alstonia scholaris).

Table 2. Variation in mean values of canopy height, bole height, tree height, canopy diameter and $\mathrm{DBH}$ of nesting tree species.

\begin{tabular}{ccccc}
\hline $\begin{array}{c}\text { Nesting tree } \\
\text { characteristic }\end{array}$ & $\begin{array}{c}\text { Senna spectabilis } \\
\text { Kahakona } \\
(\text { Mean } \pm \text { SD) }\end{array}$ & $\begin{array}{c}\text { Dymorphocalyx glabellus } \\
\text { Waliwanna } \\
\text { (Mean } \pm \text { SD) }\end{array}$ & $\begin{array}{c}\text { Alstonia scholaris } \\
\text { Rukkaththana } \\
\text { (Mean } \pm \text { SD) }\end{array}$ & p value \\
\hline Canopy height/m & $5.27 \pm 1.05^{\mathrm{B}}$ & $4.91 \pm 0.98^{\mathrm{C}}$ & $9.46 \pm 1.22^{\mathrm{A}}$ & $0.000^{*}$ \\
Bole height $/ \mathrm{m}$ & $1.82 \pm 0.71^{\mathrm{B}}$ & $1.80 \pm 0.83^{\mathrm{B}}$ & $8.22 \pm 1.90^{\mathrm{A}}$ & $0.000^{*}$ \\
Tree height $/ \mathrm{m}$ & $7.10 \pm 1.15^{\mathrm{B}}$ & $6.71 \pm 1.23^{\mathrm{B}}$ & $17.69 \pm 2.28^{\mathrm{A}}$ & $0.000^{*}$ \\
Canopy diameter/m & $8.19 \pm 6.53^{\mathrm{B}}$ & $6.51 \pm 0.81^{\mathrm{C}}$ & $12.60 \pm 0.74^{\mathrm{A}}$ & $0.000^{*}$ \\
DBH/m & $0.41 \pm 0.04^{\mathrm{B}}$ & $0.42 \pm 0.06^{\mathrm{B}}$ & $0.79 \pm 0.12^{\mathrm{A}}$ & $0.000^{*}$ \\
\hline
\end{tabular}

${ }^{*}$ Differ significantly (One-way ANOVA test, $\mathrm{p} \leq 0.05$ ) between different nesting tree species. Means followed by the same subscript letter do not differ significantly (Tukey's test $\mathrm{p} \leq 0.05$ ).

highest number of nests observed in Kahakona trees were belonged to Little Cormorants $(3.36 \pm 2.39)$. Black-headed Ibises had higher preference to construct nests on Waliwanna trees $(3.30 \pm 1.32)$ whereas, Grey Herons exhibited 
higher preference to construct nests on Rukaththana trees $(4.27 \pm 2.12)$ (Table 3 ). The mean number of nests observed in the upper, middle and lower layers in canopy were significantly different from each other. The highest number of nests was observed in middle layer followed by upper layer and lower layer (Table 4).

\section{Discussion}

Wetlands of MONP have been identified as areas of high density of waterbirds [6]. The recorded 30 species included Lesser Adjutant Stork (Leptoptilos javanicus), Asian Woollyneck (Ciconia episcopus) and Little Ringed Plover (Charadrius dubius) which are considered as globally and locally vulnerable species. Areas of MONP also have been considered as one of 70 Important Bird \& Biodiversity Areas (IBA) in Sri Lanka as it accommodates suitable habitats for these threatened species [39]. Moreover the breeding of one globally near threatened species; Black-headed Ibis and one locally near threatened species; Great Cormorant was recorded at MOR during the study period. Situated within the major Central Asian migrant pathway, Sri Lanka supports around 213 migrant bird species, including a larger proportion of waterbirds [40]. Occurrence of three species of winter visitors during the study period provides insights on availability of suitable stopover sites for migratory waterbirds within the MOR.

The highest waterbird abundance was recorded in the month of June during the study period. A greater proportion of the individuals recorded in this month comprised with two species; Little Cormorants and Black-headed Ibises. Juveniles gathering in the vicinity of the reservoir in large numbers were the reason for this observation. Bird populations are influenced by a variety of factors including the presence of suitable nesting habitats [41]. The occurrence of a comparatively

Table 3. Variations in mean number of nests of four water bird species observed in three nesting tree species.

\begin{tabular}{ccccc}
\hline & $\begin{array}{c}\text { Senna spectabilis } \\
\text { Kahakona } \\
(\text { Mean } \pm \text { SD) }\end{array}$ & $\begin{array}{c}\text { Dymorphocalyx glabellus } \\
\text { Waliwanna } \\
(\text { Mean } \pm \text { SD) }\end{array}$ & $\begin{array}{c}\text { Alstonia scholaris } \\
\text { Rukkaththana } \\
\text { (Mean } \pm \text { SD) }\end{array}$ & P value \\
\hline Little Cormorant & $3.36 \pm 2.39^{\mathrm{A}}$ & $3.28 \pm 2.46^{\mathrm{A}}$ & $2.89 \pm 2.21^{\mathrm{A}}$ & 0.537 \\
Great Cormorant & $0.21 \pm 0.41^{\mathrm{B}}$ & $0.30 \pm 0.45^{\mathrm{B}}$ & $2.38 \pm 0.74^{\mathrm{A}}$ & $0.000^{*}$ \\
Black-headed Ibis & $0.38 \pm 0.52^{\mathrm{B}}$ & $3.30 \pm 1.32^{\mathrm{A}}$ & $0.09 \pm 0.30^{\mathrm{B}}$ & $0.000^{\star}$ \\
Grey Heron & $0.12 \pm 0.32^{\mathrm{B}}$ & 0.00 & $4.27 \pm 2.12^{\mathrm{A}}$ & $0.000^{*}$ \\
\hline
\end{tabular}

${ }^{*}$ Differ significantly (One-way ANOVA test, $\mathrm{p} \leq 0.05$ ) between different nesting tree species. Means followed by the same subscript letter do not differ significantly (Tukey's test $\mathrm{p} \leq 0.05$ ).

Table 4. Variations in mean number of nests between different layers of the canopy.

\begin{tabular}{ccccc}
\hline & $\begin{array}{c}\text { Upper layer } \\
(\text { Mean } \pm \text { SD) }\end{array}$ & $\begin{array}{c}\text { Middle layer } \\
(\text { Mean } \pm \text { SD) }\end{array}$ & $\begin{array}{c}\text { Lower layer } \\
(\text { Mean } \pm \text { SD) }\end{array}$ & P value \\
\hline Mean number of nests & $3.731 \pm 1.57^{\mathrm{B}}$ & $8.901 \pm 2.67^{\mathrm{A}}$ & $3.080 \pm 1.42^{\mathrm{B}}$ & $0.000^{*}$ \\
\hline
\end{tabular}

${ }^{*}$ Differ significantly (One-way ANOVA test, $\mathrm{p} \leq 0.05$ ) between different layers in the canopy. Means followed by the same subscript letter do not differ significantly (Tukey's test $\mathrm{p} \leq 0.05$ ). 
high number of individuals of Little Cormorants and Black-headed Ibises could be partly attributed to the resulted juveniles from the nesting area at the proximity of the reservoir hence the month of June was the end of the breeding season of above two species. Although there was a great difference in abundance values between seasons, the species richness of two seasons remains more or less the same. Comparatively higher abundance in the dry season was due to the increment in the number of already recorded species, but not due to the increment of the number of species.

The Shannon-Weiner index $\left(\mathrm{H}^{\prime}\right)$ is a measure of diversity that combines species richness and their relative abundances [42]. Highest diversity was obtained in September and lowest in March. The reason for the highest diversity in September may be relatively high species richness and relative low bird abundance. Although species richness is not very low, which is 22 in the month of March the obtained lowest diversity may partly described by the very high abundance of certain species. Large number of individuals of Little Cormorants and Black-headed Ibises were observed building their nests in the trees around the reservoir in the beginning of March. The Shannon-Weiner index of waterbirds for the dry season was relatively low when compared to the wet season. The breeding season of four waterbird species were overlapped within the dry season, therefore the number of waterbirds gathered in the nesting trees around the reservoir was very high. This was the reason for the high abundance of waterbirds in the dry season. Although species richness of the dry season was close to that of the wet season diversity was low due to high bird abundance. A high year around diversity was obtained to MOR. This could be attributed to the variety of habitats provided by the reservoir. Mosaic habitat structure and habitat heterogeneity may lead to increased wildlife diversity [43]. Open water habitats are used by pelicans, cormorants and ducks while the shallow bank areas and muddy areas allow egrets, herons, ibises and spoonbills to hunt for food. Furthermore, as the reservoir dries up, the exposed bed becomes covered by grass, providing foraging grounds for many grassland associated waterbird species, e.g. herons, egrets, lapwings, thick knees and plovers. Also, grassy areas provide breeding grounds for lapwings. The floating invasive plants provide foraging habitats for a number of other different waterbird species, including Purple Swamphen and Pheasant-tailed Jacana. This variety of habitat types provided by the reservoir could be the possible reason for having a high year around waterbird diversity in MOR.

Relative abundance and commonness indicated that Little Cormorant was the most common bird followed by Black-headed Ibis. Little Cormorant is a very common resident bird species and large flocks can be seen in water bodies of the dry zone of Sri Lnaka [27]. Little Cormorants dive underwater to capture their prey, usually sit for longer period on dead trees, half-merged rocks and river banks with its wings spread to dry their wings and breeds in colonies during December to May in Sri Lanka [44] [45]. Therefore, they are well adapted to the variety of habitats offered by MOR throughout the year. When the reservoir was 
filled with water during the wet season, a large number of Little Cormorants dive in the open water for foraging purposes and they exhibited wing spread resting behavior on emerging rocks, dead trees and on the bank of the reservoir. Although the relatively low abundance of Little Cormorants was expected in the dry season due to the decrement of open water in the reservoir, the highest abundance was recorded in dry season. That was due to the resulted juveniles at the end of the breeding season. The minimum relative abundance was observed in Asian Woollyneck. Asian Woollyneck is found across South Asia and South East Asia with an estimated population up to 35,000 individuals and it is recognized as a species facing rapid population decline [11]. It is an uncommon breeding resident inhabiting the low country dry zone Sri Lanka [27]. They are more attracted to fires in grasslands and newly plowed crop fields where they capture insects trying to escape from disturbances [46]. Although land of MNOP is mainly for biodiversity and catchment conservation, some areas have been encroached by people for chena and paddy cultivation and much of the park consist of open grasslands [19]. Moreover, frequent forest fires which were conducted by poachers were recorded within the open grasslands of MONP during the dry months of the study period. A large number of gassy areas in the forest and paddy fields in the MONP could be more preferred by Asian Woollyneck, hence shifting many individuals to forest areas and this could be attributed to the minimum relative abundance of them around MOR.

Availability of habitat types varied greatly among the months with the availability of rainfall. The reservoir was eventually dried out from April to September during the dry season due to the scarcity of rainfall. The moist exposed area soon after the gradual decrement of open water of the reservoir was rich with mud flats and provided a good substrate for the emergence of grasses. The dead trees, logs and rocks were fully inundated with water when the reservoir was filled with water and they gradually emerged when the reservoir was drying out. This exposed habitats provided more platforms to stay during the foraging periods especially for diving and wading waterbirds. The invasive plant cover was absent from June to September in the dry season due to the scarcity of open water cover which required for their growth.

This study identified that waterbirds exhibit different behaviors in different habitat types. Trees around the reservoir were identified as the most utilized habitat type for both breeding and resting purposes. Colonial waterbirds of Orders Ciconiiformis and Pelicaniformis nest together in large aggregations called mixed breeding colonies of up to thousands of nests [33]. Nesting areas must provide protection from predators, nesting materials, as well as sufficient quantity and quality of foraging habitat and large waterbirds prefer the trees with higher DBH for building their nests [47] [48]. Most colonial waterbirds nest in woody trees surrounded by water, which acts as a barrier to predators [49] [50]. The large trees with higher DBH in the vicinity of the reservoir provided breeding habitats for large waterbirds such as Grey herons. Easy access to the available foraging grounds of the reservoir and the provided protection from predators 
could be partly attributed to the selection of trees around MOR as their breeding areas. Although nests are disintegrated and fallen down due to continuous heavy rain in the wet season, breeding again starts with constructing new nests in the trees in the same sites.

The Rocks was the second most utilized habitat type which accommodated both resting and comfort activities of waterbirds. Specially diving waterbirds, for example cormorants, require places to stay during their foraging periods to consume the captured prey and also to take the aim to catch the prey item during foraging. Not only diving birds, wading birds belonging to the Order Ciconiiformes were observed resting on rocks. Comfort activities, especially the wing stretching and sun basking of large flocks of cormorants were highly observed on rocks.

Open water was available as the most abundant habitat type for eight months. The majority of the waterbird species showed all the behavior categories in open water except breeding. MOR has been identified as a reservoir with a good potential for fish production. Fishing is being carried out under license from the Department of Fisheries and Aquatic Resources reservoirs [10] [19]. Based on the information gathered from fisherman during the study period it was found that around approximately 200 fisherman families make their living through fisheries in MOR. Furthermore, they launch a program of releasing the fingerlings to the MOR every year in the months of February and March. Ultimately, it provides a good food source for waterbirds, especially for the pelicans, cormorants and larger storks. Some of piscivorous waterbirds forage using group methods called mixed-flock fishing, which make the prey more accessible and correspondingly it increase the foraging efficiency [51]. Pelicans often exhibit mixed-flock fishing with cormorants [52]. This mixed-flock fishing was frequently seen between pelicans and cormorants in deeper open water areas of MOR where fish schools were available. Asian Openbills feed mainly on shelled mollusks, including fresh water snails, especially Pila globosa and also on crabs, frogs and small fish [53]. The tip of the bill is inserted into the opening of the snail and the body is extracted with the bill still under water [54]. Asian open bills were frequently found foraging in the shallow water areas near the banks of the reservoir, which accommodated a large number of freshwater snails which is a preferred prey item of them.

Areas of grass and mud were also identified as good foraging habitats for a variety of waterbirds. Muddy areas hold especially waterbird species of Charadriiformes and migratory species recorded in the study period. Water depth has an important influence on the distribution and foraging behavior of waterbirds [55]. Painted Storks prefer to feed in shallow muddy waters which have a water depth less than $25 \mathrm{~cm}$ and feed on prey items including fish and frogs [56]. As the rainfall begins after a long dry period, the water filled depressions were formed in the grassy areas on the exposed bed of the dried up reservoir. These are often characterized with shallow muddy water which supports considerable numbers of frogs, tadpoles and aquatic invertebrates attracting both adults and 
juveniles of painted storks. The mammals that frequently visit the MOR include the Asian elephant (Elephas maximus), water buffalo (Bubalus bubalis) and spotted deer (Cervus axis) [8]. Cattle Egrets were also frequently observed in grassy areas. Cattle Egrets are usually found within large grazing and browsing animals and catches small creatures disturbed by the mammals and their foraging success is much higher when foraging near a larger animal than feeding singly [57]. A large number of water buffalos were gathered in the available low amount of open water of the reservoir in the dry season for the cooling purposes. The newly emerged grass at the proximity of the reservoir also attracts elephants as well as herds of deer. This resulted in the grassy areas being manipulated into muddy areas due to the activities of these mammalian species. This indirectly increases the availability of small prey items, for example grasshoppers, soil invertebrates and frogs by habitat enrichment and it provided foods for waterbirds especially for egrets and herons.

The most underutilized habitat type was invasive plants and resting behavior was the highly observed behavior in invasive plants. Previously it was recorded that MOR has been infested with the exotic floating weed Salvinia molesta [19]. Another two invasive plants, which were recorded during the study period in MOR were identified as Eichhornia crassipes and Ludwigia sp. Interestingly, the Black-crowned Night-heron which is a nocturnal waterbird of family Ardeidae was observed resting on the invasive plant Ludwigia sp. together with other recorded species of Ardeidae and Little Cormorants. Some waterbird species prefer wetlands with plenty of floating vegetation, especially Pheasant-tailed Jacanas and Purple Swamphens. They have greatly elongated toes as an adaptation for walking over floating vegetation for foraging purposes [58] [59]. However the relatively low percentage cover of invasive plants was observed throughout the year with being completely absent in several months. This could be a possible reason for the relatively low number of waterbirds recorded in invasive plants.

Considering about the nesting site selection of waterbirds, nesting site was situated very close to the reservoir. Highly isolated patch from the main land and almost having island characteristics throughout the breeding season could be attributed to the protection from land predators. The nesting site was situated at the opposite side of the wind direction to remain shielded from speedy winds. Little Cormorants were the very first occupants of the nesting site, so as taking advantage of the plenty of the available spaces in trees to build their nests. Kahakona trees provide more angles between the branches to place the relatively smaller and rounded nests of Cormorants. Black headed ibises indicated higher preference to construct nests on Waliwanna trees as these trees provided more flat surfaces due to the bushy arrangement of leaves to construct their expanded, larger and irregular shaped nests. Grey heron had the widest wing span compared to other three nesting waterbird species in the site which may lead to choose the Rukkaththana trees with more space in the canopy.

The highest number of nests was observed in the middle layer of the canopy. The possible reason might be the reduced predation which could occur from the 
ground as well as from the air. A relatively higher protection is gained being covered by upper canopy layer which provides protection from aerial predators, for example predatory birds and also being covered by the lower canopy leads to get protection from ground predators for example fishing cats.

Moreover, waterbirds are considered as key indicators as they provide an overall view of the proper functioning and health of the wetland ecosystems [60]. By accommodating a rich waterbird community, MOR provides an insight of having ideal habitats for waterbirds. Therefore, conservation of this large reservoir is required as an important habitat for the conservation of waterbirds.

\section{Conclusion}

This study revealed that the availability of valuable habitats in the MOR varies throughout the year being a determining factor in the variation and in the high abundance and diversity of waterbirds in the place. Habitats of grass, open water and mud provided the best foraging habitats while areas with rock, dead trees/logs and invasive plants provided resting habitats for waterbirds. The best breeding habitat was trees around the reservoir and it is important to conserve the tree species in order to conserve waterbirds. The park supports a large number of habitats, which in turn supports a rich waterbird assemblage. As a preliminary study, this can be used as an approach for future research on waterbirds and to compose management and conservation plans to conserve them. By promoting the diverse bird assemblage inhabiting MONP, bird watchers and tourists can be attracted to the park, which will directly and indirectly uplift the socio-economy of the area. Moreover, conservation of the important habitats of this large reservoir is required for the conservation of waterbirds.

\section{Acknowledgements}

The authors of this manuscript want to express their deep and heartfelt appreciation to the Department of Wildlife Conservation, Sri Lanka (granted us permission by permit No. WL/3/2/5/19 to carry out this research at this protected area) and staff of Maduru Oya National Park. We are also grateful to all the members of the Wildlife Circle, academic and non-academic staff of the Department of Zoology, Faculty of Applied Sciences, University of Sri Jayewardenepura, Gangodawila, Nugegoda, Sri Lanka for their support provided.

\section{Conflicts of Interest}

The authors declare no conflicts of interest regarding the publication of this paper.

\section{References}

[1] Wetlands International (2019) Waterbird Population Estimates.

[2] Duncan, P., Hewison, A.J.M., Houte, S., Rosoux, R., Tournebize, T., Dubs, F., Burel, F. and Bretagnolle, V. (1999) Long-Term Changes in Agricultural Practices and 
Wildfowling in an Internationally Important Wetland and Their Effects on the Guild of Wintering Ducks. Journal of Applied Ecology, 36, 11-23. https://doi.org/10.1046/j.1365-2664.1999.00363.x

[3] Wang, R., Wu, F., Chang, Y. and Yang, X. (2016) Waterbirds and Their Habitat Utilization of Artificial Wetlands at Dianchi Lake: Implication for Waterbird Conservation in Yunnan-Guizhou Plateau Lakes. Wetlands, 36, 1087-1095. https://doi.org/10.1007/s13157-016-0823-y

[4] Sivaperuman, C. and Jayson, E.A. (2000) Birds of Kole Wetlands, Thrissur, Kerala. Zoos Print Journal, 15, 344-349. https://doi.org/10.11609/JoTT.ZPJ.15.10.344-9

[5] Weller, M.W. (1999) Habitat Resources and Conservation Implications. Wetland Birds. Cambridge University Press, Cambridge. https://doi.org/10.1017/CBO9780511541919

[6] Warakagoda, D. and Sirivardana, U. (2006) Status of Waterfowl in Sri Lanka. In: Fauna of Sri Lanka: Status of Taxonomy, Research and Conservation, IUCN Sri Lanka and the Government of Sri Lanka, 204-215.

[7] Wijesundara, C.S., Warakagoda, D., Sirivardana, U., Chathuranga, D., Hettiarachchi, T., Perera, N., Rajkumar, P., Wanniarachchi, S. and Weerakoon, G. (2017) Diversity and Conservation of Waterbirds in the Northern Avifaunal Region of Sri Lanka. Ceylon Journal of Science, 46, 143-155.

https://doi.org/10.4038/cjs.v46i5.7462

[8] DWC (2004) A Guide to National Parks of Sri Lanka. Second Edition, Department of Wildlife Conservation, Colombo, 155-157.

[9] Edirisinghe, G., Surasinghe, T., Gabadage, D., Botejue, M., Perera, K., Madawala, M., Weerakoon, D. and Karunarathna S. (2018) Chiropteran Diversity in the Peripheral Areas of the Maduru-Oya National Park in Sri Lanka: Insights for Conservation and Management. ZooKeys, 784, 139-162. https://doi.org/10.3897/zookeys.784.25562

[10] MEP/DWLC (1987) Master Plan: Maduru Oya National Park. Mahaweli Environment Project, Department of Wildlife Conservation.

[11] BirdLife International (2017) Ciconia episcopus (Amended Version of 2016 Assessment). The IUCN Red List of Threatened Species 2017.

[12] BirdLife International (2017) Leptoptilos javanicus (Amended Version of 2016 Assessment). The IUCN Red List of Threatened Species 2017.

[13] Weerakoon, D.K. and Goonatilleke, W.L. (2007) Diversity of Avifauna in the Wilpattu National Park, Siyoth 2, 7-15.

[14] De Alwis, S.A.U., Dayawansa, P.N., Weerakoon, D., Wijesinghe, M.R. and Yapa W.B. (2007) Biodiversity Baseline Survey: Wasgomuwa National Park.

[15] DWC (2008) Biodiversity Baseline Survey: Minneriya National Park. Department of Wildlife Conservation, Colombo.

[16] Hettige, U.B., Wikramasinghe, L.J.M., Piyadarshana, T., Gunawardana, K., Perera, L.I. and Manorathna, A. (2000) Fauna of Gal-oya National Park, Sri Lanka. Naturalist, 3, 55-60.

[17] De Silva, M. (2004) The Yala Wildlife Reserves Biodiversity and Ecology. Wildlife Heritage Trust, Colombo.

[18] Gabadage, D.E., Botejue, W.M.S., Surasinghe, T.D., Bahir, M.M., Madawala, M.B., Dayananda, B., Weeratunga, V.U. and Karunarathna, D.S. (2015) Avifaunal Diversity in the Peripheral Areas of the Maduruoya National Park in Sri Lanka: With Conservation and Management Implications. Journal of Asia-Pacific Biodiversity, 8 , 
121-132. https://doi.org/10.1016/j.japb.2015.04.005

[19] IUCN (2006) IUCN Sri Lanka and the Central Environmental Authority: National Wetland Directory of Sri Lanka, Colombo, Sri Lanka.

[20] Gregory, R.D., Gibbons, D.W. and Donald, P.F. (2004) Bird Census and Survey Techniques. In: Sutherland, W.J., Newton, I. and Green, R.E., Eds., Bird Ecology and Conservation: A Handbook of Techniques, Ecology and Conservation, Oxford University Press, Oxford, 17-56.

https://doi.org/10.1093/acprof:oso/9780198520863.003.0002

[21] Sutherland, W.J. (2006) Ecological Census Techniques: A Handbook. Cambridge University Press, Cambridge. https://doi.org/10.1017/CBO9780511790508

[22] Lorenzón, R.E., Beltzer, A.H., Peltzer, P.M., Olguin, P.F., León, E.J., Sovrano, L. and Ronchi-Virgolini, A.L. (2017) Habitat-Mediated Influence of Water-Level Fluctuations on Waterbird Occurrence in Floodplain Wetlands of the Parana River, Argentina. River Research and Applications, 33, 1494-1505.

https://doi.org/10.1002/rra.3199

[23] González-Gajardo, A., Sepúlveda, P.V. and Schlatter, R. (2009) Waterbird Assemblages and Habitat Characteristics in Wetlands: Influence of Temporal Variability on Species-Habitat Relationships. Waterbirds, 32, 225-234. https://doi.org/10.1675/063.032.0203

[24] Yardi, K.D., Bharucha, E. and Girade, S. (2019) Post-Restoration Monitoring of Water Quality and Avifaunal Diversity of Pashan Lake, Pune, India Using a Citizen Science Approach. Freshwater Science, 38, 332-341. https://doi.org/10.1086/703440

[25] Jayathilake, M.B. and Chandrasekara, W.U. (2015) Variation of Avifaunal Diversity in Relation to Land-Use Modifications around a Tropical Estuary, the Negombo Estuary in Sri Lanka. Journal of Asia-Pacific Biodiversity, 8, 72-82. https://doi.org/10.1016/j.japb.2015.02.001

[26] Bellio, M.G., Kingsford, R.T. and Kotagama, S.W. (2009) Natural versus Artificial-Wetlands and Their Waterbirds in Sri Lanka. Biological Conservation, 142, 3076-3085. https://doi.org/10.1016/j.biocon.2009.08.007

[27] Harrison, J. and Worfolk, T. (2011) A Field Guide to the Birds of Sri Lanka. 2nd Edition, Oxford University Press, New York.

[28] BirdLife International (2020) Species Factsheet: In IUCN Red List for Birds. http://www.birdlife.org

[29] Altman, J. (1974) Observational Study of Behaviors: Sampling Methods. Behaviour, 49, 227-267. https://doi.org/10.1163/156853974X00534

[30] Indika, A.V.D.J. (2014) Habitat Use of Diurnal Water Fowl in Annawilundawa Ramsar Wetland of Northwestern of Sri Lanka. Doctoral Dissertation, University of Sri Jayewardenepura, Gangodawila.

[31] Luo, K., Wu, Z., Bai, H. and Wang, Z. (2019) Bird Diversity and Waterbird Habitat Preferences in Relation to Wetland Restoration at Dianchi Lake, South-West China. Avian Research, 10, 21. https://doi.org/10.1186/s40657-019-0162-9

[32] Priyanjali, Y.A.G.S. (2011) Diversity Abundance and Habitat Use of Diurnal Water Birds of Order Ciconiiformes at the Annaiwilundawa Ramsar Wetland Sanctuary, Sri Lanka. BSc Thesis, University of Sri Jayewardenepura, Gangodawila.

[33] Roshnath, R. and Sinu, P.A. (2017) Nesting Tree Characteristics of Heronry Birds of Urban Ecosystems in Peninsular India: Implications for Habitat Management. Current Zoology, 63, 599-605. https://doi.org/10.1093/cz/zox006

[34] Sultana, A., Khan, A., Yahya, H.S.A. and Kaul, R. (2006) Nesting Ecology of Cattle 
Egrets and Little Egrets in Amroha, Uttar Pradesh, India. Forktail, 22, 133.

[35] Feldpausch, T.R., Banin, L., Phillips, O.L., Baker, T.R., Lewis, S.L., Quesada, C.A., Affum-Baffoe, K., Arets, E.J., Berry, N.J., Bird, M. and Brondizio, E.S. (2011) Height-Diameter Allometry of Tropical Forest Trees. Biogeosciences, 8, 1081-1106. https://doi.org/10.5194/bg-8-1081-2011

[36] Magurran, A.E. (2013) Measuring Biological Diversity. John Wiley \& Sons, Hoboken.

[37] Ogendi, G. and Ondieki, R. (2020) Avian and Habitat Diversity in the Semi-Arid Lands of Baringo South, Kenya. Open Journal of Ecology, 10, 518-536. https://doi.org/10.4236/oje.2020.108033

[38] Takele, S. and Endale, G. (2019) Species Composition and Relative Abundance of Lakeshore Bird Species around Lake Hawassa, Ethiopia. International Journal of Biodiversity and Conservation, 11, 175-182. https://doi.org/10.5897/IJBC2018.1260

[39] BirdLife International (2020) Important Bird Areas Factsheet: Madura Oya. In IUCN Red List for Birds. http://www.birdlife.org

[40] Weerakoon, D.K. and Gunawardena, K. (2012) The Taxonomy and Conservation Status of Birds in Sri Lanka. In: Weerakoon, D.K. and Wijesundara, S., Eds., The National Red List 2012 of Sri Lanka: Conservation Status of the Fauna and Flora, Ministry of Environment, Colombo, 114-117.

[41] Forcey, G.M., Linz, G.M., Thogmartin, W.E. and Bleier, W.J. (2007) Influence of Land Use and Climate on Wetland Breeding Birds in the Prairie Pothole Region of Canada. Canadian Journal of Zoology, 85, 421-436. https://doi.org/10.1139/Z07-005

[42] Magurran, A.E. (2005) Biological Diversity. Current Biology, 15, 116-118. https://doi.org/10.1016/j.cub.2005.02.006

[43] Turner, I.M. and Corlett, R.T. (1996) The Conservation Value of Small, Isolated Fragments of Lowland Tropical Rain Forest. Trends in Ecology \& Evolution, 11, 330-333. https://doi.org/10.1016/0169-5347(96)10046-X

[44] Ali, S. and Ripley, S.D. (1968) Handbook of the Birds of India and Pakistan: Together with Those of Nepal, Sikkim, Bhutan and Ceylon (Vol. 1). Oxford University Press, Oxford.

[45] Zeenath, C. and Zacharias, V.J. (2010) Foraging Behaviour and Diving Pattern of Little Cormorant Phalacrocorax niger (Vieillot) (Pelecaniformes: Phalacrocoracidae) at Kallampara Backwaters, Kerala, India. Journal of Threatened Taxa, 2, 1382-1386. https://doi.org/10.11609/JoTT.o1819.1382-6

[46] Hancock, J.A., Kushlan, J.A. and Kahl, M.P. (1992) Storks, Ibises, and Spoonbills of the World. Academic Press, London.

[47] Hafner, H. (2000) Heron Nest Site Conservation. In: Kushlan, J.A. and Hafner, H., Eds., Heron Conservation, Academic Press, San Diego, 201-217.

[48] Koju, R., Maharjan, B., Gosai, K.R., Kittur, S. and Sundar, K.G. (2020) Ciconiiformes Nesting on Trees in Cereal-Dominated Farmlands: Importance of Scattered Trees for Heronries in Lowland Nepal. Waterbirds, 42, 355-453. https://doi.org/10.1675/063.042.0401

[49] Rodgers, J.R., James, A., Stephen, T., Schwikert and Shapiro-Wenner, A. (1996) Nesting Habitat of Wood Storks in North and Central Florida, USA. Colonial Waterbirds, 19, 1-21. https://doi.org/10.2307/1521802

[50] White, C.L., Frederick, P.C., Main, M.B. and Rodgers, J.A. (2005) Nesting Island Creation for Wading Birds. Wildlife Ecology and Conservation Department, Florida Cooperative Extension Service, Institute of Food and Agricultural Sciences, Univer- 
sity of Florida, Circular, 1473. https://doi.org/10.32473/edis-uw223-2005

[51] Frederick, P.C. (2002) Wading Birds in the Marine Environment. In: Burger, J. and Schreiber, E.A., Eds., Biology of Marine Birds, CRC Press, Boca Raton, 617-655.

https://doi.org/10.1201/9781420036305.ch19

[52] Giokas, S., Maximiadi, M., Kassara, C., Alexandrou, O. and Catsadorakis, G. (2020) Mixed-Species Flock Fishing in Dalmatian Pelicans: Patterns and Benefits. Ardea, 108, 65-72. https://doi.org/10.5253/arde.v108i1.a9

[53] Kahl, M.P. (1971) Food and Feeding Behavior of Openbill Storks. Journal für Ornithologie, 112, 21-35. https://doi.org/10.1007/BF01644077

[54] Jinnath, A., Mansur, A., Saikia, M.K. and Saikia, P.K. (2016) Food and Feeding Behaviour of Openbill Stork (Anastomus oscitans) in Assam, India. Journal of Global Biosciences, 5, 4188-4196.

[55] Nagarajan, R. and Thiyagesan, K. (1996) Waterbirds and Substrate Quality of the Pichavaram Wetlands, Southern India. Ibis, 138, 710-721.

https://doi.org/10.1111/j.1474-919X.1996.tb04773.x

[56] Kalam, A. and Urfi, A.J. (2008) Foraging Behaviour and Prey Size of the Painted Stork. Journal of Zoology, 274, 198-204.

https://doi.org/10.1111/j.1469-7998.2007.00374.x

[57] Grubb, T.C. (1976) Adaptiveness of Foraging in the Cattle Egret. The Wilson Bulletin, 88, 145-148.

[58] Mahaulpatha, W.A.D., Mahaulpatha, W.M.T. and Wasantha, K.A.L. (2008) Effects of Water-Level Fluctuation and Invasive Water Plants on Pheasant-Tailed Jacana (Hydrophasianus chirugus) at the Annaiwilundawa Ramsar Site of Northwestern Sri Lanka. Wetlands Ecology and Management, 16, 33-42. https://doi.org/10.1007/s11273-007-9045-7

[59] Norman, F.I. and Mumford, L. (1985) Studies on the Purple Swamphen, Porphyrio porphyrio, in Victoria. Wildlife Research, 12, 263-278. https://doi.org/10.1071/WR9850263

[60] Cornelius, C., Navarrete, S.A. and Marquet, P.A. (2001) Effects of Human Activity on the Structure of Coastal Marine Bird Assemblages in Central Chile. Conservation Biology, 15, 1396-1404. https://doi.org/10.1046/j.1523-1739.2001.00163.x 


\section{Appendix A. Common Ethogram for Waterbirds}

\begin{tabular}{ll}
\hline Behavior & Description \\
\hline Resting & Resting of waterbird comprised of loafing, sleeping and roosting. \\
1. Loafing Waterbird may be simply standing or sitting down on the ground or shows \\
a variety of fatigue or relaxing moves. \\
2. Sleeping is with standing or sitting on ground or holding themselves motionless in \\
water. Eyes are closed with neck held in normal or retracted position or with the \\
bill tucked under scapular. \\
3. Roosting-birds choose a site to sleep and rest as trees.
\end{tabular}

Feeding All the behaviors associated with actively searching for food, capturing it, and manipulating or ingesting

1. Pecking, penetration of substrate by less than one-quarter of bill length to catch prey items. Use visual means for detecting prey items in water's edge or muddy areas out of water.

2. Probing, penetration of substrate by more than one-quarter of bill length using tactile means to discover buried prey.

3. Ploughing-moving slightly opened bills rapidly through the water in shallow waters. The bird immerses the lower half of its bill in water at a shallow angle and run forward very quickly.

4. Sweeping, side to side movements of bill introduced in water

5. Stabbing, walk slowly through shallow water searching for prey or stood motionless watching for the prey and stabbing it when found.

6. Plunging head and neck enter in water to catch prey

7. Diving

8. Plung diving

9. Up ending

10. Head submergence

11. Filtering

Locomotion Moving from one place to another by walking, running (speed faster than walking with its head held high and extended) swimming (the waterbird is completely in the water and moving either treading or propelling forward legs) and flying (the waterbird rises up out of the substrate) into flight, and lands back in the substrate or continues flying out of sight).

Comfort Comfort activities are further divided into preening, bathing ant stretching.

activities 1. Preening, care of body surface and relative activities which involve the contact between the bill and the feathers.

2. Bathing, Dipping the head in water accompanied by the beating of wings as also by short dives.

3. Stretching.

Agonistic This range from simple threat and avoidance to energetically costly chasing in pursuit flights.

Alert Waterbird in the alert mode, remains motionless, with its eyes open and with the neck fully extended in a posture of standing on the ground or water. Also usually held their heads further up stretched and watched and listened for potential intruders, predators or disturbance.

Other Any other behavior that the animal is exhibiting that is not described within the above ethogram categories. 


\section{Appendix B. Species Composition and Commonness of the Waterbird} Species in and around MONP during the Study Period

\begin{tabular}{|c|c|c|c|c|c|}
\hline Order & Family & Common name & Scientific name & NCS & GCS \\
\hline \multirow{5}{*}{ Pelecaniformes } & \multirow{3}{*}{ Phalacrocoracidae } & Great Cormorant & Phalacrocorax carbo & NT & LC \\
\hline & & Indian Cormorant & Phalacrocorax niger & LC & LC \\
\hline & & Little Cormorant & Phalacrocorax fuscicollis & LC & LC \\
\hline & Anhingidae & Oriental Darter & Anhinga melanogaster & LC & NT \\
\hline & Pelecanidae & Spot-billed Pelican & Pelicans philippensis & LC & NT \\
\hline \multirow{14}{*}{ Ciconiiformes } & \multirow{8}{*}{ Ardeidae } & Great White Egret & Ardea alba & LC & LC \\
\hline & & Intermediate Egret & Mesophoyx intermedia & LC & LC \\
\hline & & Little Egret & Egretta garzetta & LC & LC \\
\hline & & Cattle Egret & Bubulcus ibis & LC & LC \\
\hline & & Grey Heron & Ardea cinerea & LC & LC \\
\hline & & Indian Pond -heron & Ardeola grayii & LC & LC \\
\hline & & Purple Heron & Ardea purpurea & LC & LC \\
\hline & & Black-crowned Night-heron & Nycticorax nycticorax & NT & LC \\
\hline & \multirow{2}{*}{ Threskiornithidae } & Black-headed Ibis & Threskiornis melanocephalus & LC & NT \\
\hline & & Eurasian Spoonbill & Platalea leucorodia & LC & NT \\
\hline & \multirow{4}{*}{ Ciconiidae } & Painted Stork & Mycteria leucocephala & LC & NT \\
\hline & & Asian Openbill & Anastomus oscitans & LC & LC \\
\hline & & Asian Woollyneck & Ciconia episcopus & NT & VU \\
\hline & & Lesser Adjutant Stork & Leptoptilos javanicus & VU & VU \\
\hline \multirow{8}{*}{ Charadriiformes } & Recurvirostridae & Black-winged Stilt & Himantopus himantopus & LC & LC \\
\hline & \multirow{2}{*}{ Scolopacidae } & Common Sandpiper & Tringa hypoleucos & & LC \\
\hline & & Common Greenshank & Tringa nebularia & & LC \\
\hline & Jacanidae & Pheasant-tailed Jacana & Hydrophasianus chirurgus & LC & LC \\
\hline & \multirow{2}{*}{ Charadridae } & Red-wattled Lapwing & Vanellus indicus & LC & LC \\
\hline & & Little Ringed Plover & Charadrius dubius jerdoni & $\mathrm{VU}$ & LC \\
\hline & Laridae & Whiskered Tern & Chlidonias hybridus & & LC \\
\hline & Burhinidae & Great Thick Knee & Esacus recurvirostris & LC & NT \\
\hline Podicipediformes & Podicipedidae & Little Greb & Tachybaptus ruficollis & LC & LC \\
\hline Gruiformes & Rallidae & Purple Swamphen & Porphyrio porphyrio & LC & LC \\
\hline Anseriformes & Anatidae & Lesser Whistling Duck & Dendrocygna javanica & LC & LC \\
\hline
\end{tabular}

NCS = National conservation status: GCS = Global conservation status: LC = Least Concern: NT = Near Threatened: $\mathrm{V}=$ Vulnerable: ${ }^{*}$ Reference sources: BirdLife International 2017: BirdLife International 2020. 
Appendix C. Relative Abundance of Waterbird Species

\begin{tabular}{|c|c|c|}
\hline Abundance rank & Species & Relative abundance (\%) \\
\hline 1 & Little Cormorant & 64.8123 \\
\hline 2 & Black-headed Ibis & 9.0239 \\
\hline 3 & Asian Open bill & 6.1879 \\
\hline 4 & Painted Stork & 5.4565 \\
\hline 5 & Spot-billed Pelican & 2.4993 \\
\hline 6 & Grey Heron & 2.0198 \\
\hline 7 & Little Egret & 1.6154 \\
\hline 8 & Intermediate Egret & 1.5742 \\
\hline 9 & Purple Heron & 1.3514 \\
\hline 10 & Cattle Egret & 0.9808 \\
\hline 11 & Great White Egret & 0.9300 \\
\hline 12 & Great Cormorant & 0.5788 \\
\hline 13 & Indian Pond -heron & 0.4286 \\
\hline 14 & Red-wattled Lapwing & 0.3947 \\
\hline 15 & Indian Cormorant & 0.3487 \\
\hline 16 & Whiskered Tern & 0.2325 \\
\hline 17 & Black-crowned Night -heron & 0.2034 \\
\hline 18 & Black Winged Stilt & 0.1985 \\
\hline 19 & Common Sandpiper & 0.1889 \\
\hline 20 & Common Greenshank & 0.1622 \\
\hline 21 & Lesser Whistling Duck & 0.1380 \\
\hline 22 & Little Ringed Plover & 0.1210 \\
\hline 23 & Purple Swamphen & 0.1065 \\
\hline 24 & Little Greb & 0.1041 \\
\hline 25 & Great Thick Knee & 0.1017 \\
\hline 26 & Oriental Darter & 0.0871 \\
\hline 27 & Lesser Adjutant & 0.0823 \\
\hline 28 & Eurasian Spoon Bill & 0.0387 \\
\hline 29 & Pheasant-Tailed Jacana & 0.0169 \\
\hline 30 & Asian Woollyneck & 0.0145 \\
\hline
\end{tabular}




\section{Appendix D. Commonness of the Waterbirds in and around} MOR

\begin{tabular}{|c|c|c|c|}
\hline Common name & $\begin{array}{l}\text { Number of visits } \\
\text { seen the bird }\end{array}$ & $\begin{array}{l}\text { Percentage of the } \\
\text { bird occurrence }\end{array}$ & $\begin{array}{l}\text { Commonness } \\
\text { of the bird }\end{array}$ \\
\hline Great Cormorant & 10 & 83.3 & $\mathrm{VC}$ \\
\hline Indian Cormorant & 12 & 100 & VC \\
\hline Little Cormorant & 12 & 100 & VC \\
\hline Oriental Darter & 4 & 33.3 & UC \\
\hline Spot-billed Pelican & 7 & 58.3 & $\mathrm{C}$ \\
\hline Great White Egret & 12 & 100 & VC \\
\hline Intermediate Egret & 12 & 100 & VC \\
\hline Little Egret & 12 & 100 & VC \\
\hline Cattle Egret & 12 & 100 & VC \\
\hline Grey heron & 12 & 100 & VC \\
\hline Indian Pond-heron & 12 & 100 & VC \\
\hline Purple Heron & 12 & 100 & VC \\
\hline Black-crowned Night-heron & 2 & 16.7 & RA \\
\hline Black Headed Ibis & 10 & 83.3 & VC \\
\hline Eurasian Spoon Bill & 4 & 33.3 & UC \\
\hline Painted Stork & 12 & 100 & VC \\
\hline Asian Openbill & 12 & 100 & VC \\
\hline Asian Woollyneck & 4 & 33.3 & UC \\
\hline Lesser Adjutant & 10 & 83.3 & VC \\
\hline Black Winged Stilt & 12 & 100 & VC \\
\hline Common Sandpiper & 9 & 75 & VC \\
\hline Common Greenshank & 9 & 75 & VC \\
\hline Pheasant-Tailed Jacana & 3 & 25 & UC \\
\hline Red-wattled Lapwing & 12 & 100 & VC \\
\hline Little Ringed Plover & 10 & 83.3 & VC \\
\hline Whiskered Tern & 11 & 91.7 & VC \\
\hline Great Thick Knee & 9 & 75 & VC \\
\hline Little Greb & 8 & 66.7 & $\mathrm{C}$ \\
\hline Purple Swamphen & 6 & 50 & $\mathrm{C}$ \\
\hline Lesser Whistling Duck & 3 & 25 & UC \\
\hline Total number of visits & 12 & & \\
\hline
\end{tabular}

$\mathrm{VC}=$ very common: $\mathrm{C}=$ Common: $\mathrm{UC}=$ uncommon: $\mathrm{RA}=$ Rare. 